\title{
Performance of The Village Goverment in Implementing The Village Information System Program in Sungai Bawang Village
}

\author{
Sujianto, Siti Anisa \\ Universitas Riau \\ e-mail: sujianto@ lecturer.unri.ac.id
}

\begin{abstract}
The performance of the Sungai Bawang Village Government in the Village Information System program can be seen from the implementation process. This study focuses on the performance of the Sungai Bawang village government in the Village Information System Program in order to realize the vision and mission of Kuantan Singingi Regency. But the realization in the field that the performance of the Sungai Bawang village government in the Village Information System program did not have a significant impact. In terms of productivity indicators, after the implementation of the Village Information System program the performance of the Sungai Bawang Village Government did not change significantly. Indicators of service quality, the quality of services received by the community before and after the implementation of the Village Information System program have no real impact, because the services provided are still the same, still not based on online information technology. Indicator of responsiveness can be seen that third parties are not committed to the agreed work contract agreement. Responsibility Indicator, the standard used as a reference in implementing the Village Information System program is Kuantan Singingi District Regulations No. 57 of 2017 concerning Village Information Systems and their derivatives namely Standard Operating Procedure (SOP) for Village Information Systems. Accountability indicators, there is an element of political interest in the Village Information System program. The purpose of this study was to determine the performance of the Sungai Bawang village government in the implementation of the Village Information System program and its inhibiting factors. The research method uses qualitative by emphasizing the concept of performance measurement. The techniques used in collecting data are observation, interviews, documentation, and literature. The results showed that the performance of the Sungai Bawang village government was still not optimal. The inhibiting factor is the non-commitment of the third party in carrying out the responsibility, the Village Information System program is influenced by the political interests of certain groups so that the Village Information System program does not run as contained in Kuantan Singingi No. 57 of 2017 concerning Village Information Systems.
\end{abstract}

Keywords: performance, management, actuating, village information system

\section{Abstrak}

Kinerja Pemerintah Desa Sungai Bawang dalam program Sistem Informasi Desa bisa dilihat dari proses pelaksanannya. Penelitian ini fokus melihat kinerja pemerintah Desa Sungai Bawang dalam pelaksanaan Program Sistem Informasi Desa dalam rangka mewujudkan visi misi Kabupaten Kuantan Singingi. Namun realisasinya dilapangan bahwa kinerja pemerintah desa Sungai Bawang dalam pelaksanaan program Sistem Informasi Desa tidak memberikan dampak yang signifikan. Ditinjau dari indikator produktivitas, pasca diterapkannya program Sistem Informasi Desa kinerja Pemerintah Desa Sungai Bawang tidak ada perubahan secara signifikan. Indikator kualitas layanan, kualitas layanan yang diterima masyarakat sebelum dan sesudah diterapkannya program Sistem Informasi Desa tidak berdampak nyata, karena pelayanan yang diberikan juga masih sama masih manual belum berbasis teknologi informasi secara sistem online. Indikator responsivitas terlihat bahwa pihak ketiga tidak 
komitmen kepada perjanjian kontrak kerja yang telah disepakati. Indikator Responsibilitas, standar yang dijadikan acuan dalam mengimplementasikan program Sistem Informasi Desa ini adalah Peraturan Bupati Kabupaten Kuantan Singingi No. 57 Tahun 2017 tentang Sistem Informasi Desa serta turunannya yaitu Standar Operasional Prosedur (SOP) Sistem Informasi Desa. Indikator akuntabilitas, terdapat unsur kepentingan politik dalam program Sistem Informasi Desa. Tujuan penelitian adalah untuk mengetahui kinerja pemerintah desa Sungai Bawang dalam implementsi program Sistem Informasi Desa dan faktor penghambatnya. Metode penelitian menggunakan kualitatif dengan menekankan konsep pengukuran kinerja. Teknik yang digunakan dalam mengumpulkan data adalah observasi, wawancara, dokumentasi dan literatur. Hasil penelitian menunjukkan bahwa kinerja pemerintah desa Sungai Bawang masih belum optimal. Adapun faktor penghambatnya adalah tidak komitmennya pihak ketiga dalam menjalankan tanggung jawab, program Sistem Informasi Desa dipengaruhi oleh kepentingan politik kelompok tertentu sehingga program Sistem Informasi Desa tidak berjalan sebagaimana yang terdapat dalam Peraturan Bupati Kuantan Singingi No. 57 Tahun 2017 tentang Sistem Informasi Desa.

Kata Kunci : Kinerja, Manajemen, Pelaksanaan, Sistem Informasi Desa

\section{INTRODUCTION}

The era of the industrial revolution 4.0 has had a significant influence on the development of organizational dynamism including at village level organizations. Village government in the 4.0 era was demanded to make changes to the organizational design paradigm towards increasing accountability, transparency and high responsiveness in order to improve public services to the community. The village government is demanded that improving performance no longer be measured based on the process adopted so far with the manual concept of direct face to face, but the era of the industrial revolution 4.0 prioritizes more dynamic processes based on information technology to produce more effective and efficient outputs. The common objective of digitizing and integrating information in government is to leverage the benefits of technology Weerakkody and Choudrie in (Mohamad Abu Ghazaleh, 2018). The existence of information technology will certainly require the village government to implement egovernment. E-government is not only a generic term for electronic administrations of government processes but it also uses data innovation and worldwide Web to strengthen government operations and communication with citizens In order to improve public services need to be supported by reliable human resources Sharma in (Nadia Butt, 2018) Reliable resources will certainly have an impact on optimal performance results.

Performance has become an interesting subject to be discussed in the context of public management. Performance can be seen from two aspects, namely the performance of employees (individuals) and organizational performance. Performance is a picture of the level of achievement of the implementation of tasks in an organization in an effort to realize the goals, objectives, mission and vision of the organization Bastian in (Prihati, 2018). Whereas Sudarto in (Linda Muchacha Paramitha) revealed that performance is the result or performance of an organization carried out by individuals that can be demonstrated concretely and can be measured. Performance can be said as the final result (output) of a process of activities carried out by all elements of the organization against the resources used (input). An organization must have interrelationship between the performance of each member (Individual performance) in the organization and organizational performance (organizational performance). According to Widodo in (Linda Muchacha Paramitha) performance is an activity and perfects it in accordance with its responsibilities with expected results. 
The member performance explains to what extent the individual has carried out the main task so that it can deliver the results set by the group / organization. (Tangkilisan, 2005) states that humans are a very important element, because humans always play an active and dominant role in every organization. Human resources are subjects as active actors who drive the running of an organization. Human resources need to be supported with the skills, skills, experience and education that can be utilized by an organization. Besides the placement of human resources also need to be adjusted to the capabilities of each individual in order to work in accordance with the given job desk. Sedarmayanti in (Sagita, 2017) argues that performance is the result of the work of the entire organization, which can be proven and the results of work produced in accordance with predetermined standards. So with the predetermined standards will be achieved the objectives of an organization as stated in the vision and mission of the organization.

The vision and mission of the organization will be achieved if managed properly. Management is a process of planning, organizing, leading and supervising the work of members of the organization and using all available organizational resources to achieve organizational goals clearly stated Stoner and Freeman in (Wibowo, 2007). Management according to George R. Terry in (Badrudin, 2007). George R. Terry defines management as a unique process consisting of planning, organizing, mobilizing, and controlling actions taken to determine and achieve predetermined goals through the use of human and other resources. It can be concluded that management is the process of using organizational resources by using others to achieve organizational goals effectively and efficiently. Meanwhile, in order to achieve organizational goals, real actions must be taken in implementation.

Implementation in management is better known as the language of program implementation (Badrudin, 2007). Implementation boils down to activities, the actions, actions and mechanisms of a system. The expression mechanism means that the implementation is not just an activity, but an activity that is planned and carried out seriously based on certain norms to achieve the objectives of the activity. Wahab in (Rahmatullah, 2017) said that policy implementation is the implementation of basic policy decisions, usually in the form of laws, but can also take the form of important executive orders or decisions or judicial bodies' decisions typically, these decisions identify the problem being overcome, explicitly state the goals / objectives to be achieved, and various ways to structure / regulate the implementation process. Chief J. O. Udoji in (Andri Putra Kesmawan, 2014) that "The implementation of policy is an important matter even more important than policy making.

The vision and mission of an organization will be achieved if the organization has a policy, program, project or activity so that objectives can be realized. Kuantan Singingi Regency is the only regency in Riau Province that has a Village Information System policy that is contained in the Regulations of the Kuantan Singingi Regency Number 57 of 2017 concerning Village Information Systems. Village Information System (SID) is a set of tools and processes for utilizing data and information to support resource management at the village level. (SID) is a system consisting of software (hardware), hardware (hardware) and brainware (users) managed by the Village Government both offline and online with the aim of improving the quality of public services.

While the function and content of the Village Information System (SID) program in the article are:

1. Data storage and management media (village potential data, education data, health data, population data, poverty data, village development data, rural development data, financial data, economic data, socio-cultural data, village government data and other relevant data needs) namely managing and disseminating SID in accordance with statutory regulations.

2. Village government information and communication media, i.e. all village information that can be accessed by the village community and all stakeholders in accordance with statutory provisions by providing SID instruments; publish information periodically (information that must be announced at least 6 (six) months, such as: information on village administration, development 
implementation, financial reports, etc.) and / or available at any time accurate information (information on decisions, agreements with other parties, information and policies conveyed in open meetings). While the communication meant here is two-way communication carried out by the village government to the community or vice versa.

3. Administrative services and village financial management in order to realize transparency and accountability.

The Village Information System (SID) is a program of the District Head of Kuantan Singingi, which is under the responsibility of the Social and Village Empowerment (DSPMD) Social Service and the Statistical Information and Communication Communication Office (DKISP) and third parties as facilitators in this case are PT. Indonesia Comnets Plus (PT. ICON +). The responsibility of the Social Service Agency for Community and Village Empowerment (DSPMD) is to coordinate the development, fostering and compiling Standard Operating Procedures (SOP) for the application of Village Information Systems (SID). The Statistical Information and Communication Office (DKISP) as the technical implementer is responsible for developing, integrating SID with information systems at the district level, and managing information systems and information technology to support and facilitate Village Information Systems (SID) at the village level. While PT. Indonesia Comnets Plus (ICON +), which is a facilitator providing internet network infrastructure in the form of wifi installed in public areas and village offices, providing websites with the domain "desa.id" and supporting applications for the Village Information System (SID) and providing training to village officials in this is the village administrator and operator. The targets of the Village Information System (SID) program are village government organizations, village officials and village communities.

In order to achieve the objectives of the Village Information System program, the Village Information System program needs to be implemented. Implementation is an important aspect of the entire public policy process. Van Meter and Van Horn in Mulyadi (2016: 57) formulate the implementation of public policy as: "actions taken by public bodies directed to achieve the objectives set in the previous set of decisions. These actions include efforts to turn decisions into operational actions. Whereas the implementation of policies in principle is a way for a policy to achieve its objectives. Nothing more and nothing less. To implement public policy, there are two steps (Nugroho, 2017: 728), which are directly implemented in the form of programs or through the formulation of derivative policies I public policy derivatives. The Village Information System Program is a program that can be implemented directly which is revealed in the Village Information System Operational Procedure Standards that in implementing the Village Information System program it needs to be coordinated with DSPMD and DKISP.

Sungai Bawang Village is an ex-transmigration village that has implemented a Village Information System program and has a village website with the link www.sungaibawang.com even before entering the Village Information System program created by local village youth. However, the realization in the Sungai Bawang Village website does not contain all the indicators as stipulated in article 6 of the Kuantan Singingi Regency Regulations No. 57 of 2017 concerning Village Information Systems that the village website must contain village data (village potential data, education data, health data, population data, poverty data, village development data, rural area development data, financial data, economic data, socio-cultural data, Village Government data, and other data as needed, but the fact in the field shows that the performance of the Sungai Bawang Village Government after the implementation of the Village Information System program is as follows:

After the implementation of the Village Information System program in Sungai Bawang Village did not have a significant impact, this was because the implementation of the Village Information System program was limited to installing wifi at the Sungai Bawang Village Office which was only used by a number of communities, especially village youth. Whereas in addition to having wifi installed in the 
village office, the village must also be given a website as a medium for data storage, communication to the community and administrative services. The performance of the Sungai Bawang Village Government both before and after the implementation of the Village Information System program is the same. This is because administrative services cannot yet be done through the website "Sungaibawang.com". whereas in Article 6 point $d$ it should require the Village Government to perform administrative services through the website. Sungai Bawang Village Government has not received training on how to implement the Village Information System program as listed in Article 7 point c by a third party (PT.ICON +). Whereas in addition to wifi and website, the village government should also have the right to receive training to improve the quality of Human Resources, especially those who become village administrators and operators. The purpose of this study is to analyze the performance of Sungai Bawang Village Government and its problems after the implementation of the Village Information System program.

\section{METHOD}

This study uses a qualitative method of phenomenological approach to explore the meaning of the concept of "village government performance". Qualitative is a qualitative research is a method for exploring and understanding the meaning that by a number of individuals or groups of people ascribed to Jamalludin's social problems in or humanity (Nilawati, 2016). A phenomenological study illustrates the meaning of experiences experienced from a phenomenon from the perspective of the individuals who have experienced it. It is important to understand individual experiences or shared experiences of a phenomenon to develop a deeper understanding of its features (Creswell) in (Tantut Susanto, 2018). This research focuses on the performance of the Sungai Bawang Village Government in implementing the Village Information System program.

\section{FINDING AND DISCUSSION}

Sungai Bawang Village is one of the villages in Singingi Subdistrict, Kuantan Singingi District, which has implemented a Village Information System program and has a website with the link "Sungaibawang.com" which is expected to implement the Village Information System program capable of improving public services based on information technology online to people who indirectly demand the Village Government to improve their performance and ability to be literate with information technology. Therefore the performance of the Sungai Bawang Village Government is the main thing that shows how far the level of ability to carry out tasks in order to achieve organizational goals can be implemented well. This study uses a theory put forward by Agus Dwiyanto (2006: 50) measuring the performance of public bureaucracy including the following:

1. Productivity

The concept of productivity not only measures the level of efficiency, but also the effectiveness of the service. Productivity is generally understood as the ratio between input and output. The concept of productivity was deemed too narrow and then the General Accounting Office (GAO) tried to develop a broader measure of productivity by including how much public service had expected results as an important performance indicator. Regarding productivity, the researcher conducted an interview with the Head of the Sungai Bawang Village Administration who said that "After the implementation of the SID program in Sungai Bawang Village, it did not have a significant impact on the performance of the village apparatus in providing services to the community. This is because the activities of the SID program have not been fully realized. The Village Information System Program is only in the stage of installing wifi, 
while the website has not yet been provided. So that in providing services to the community it still uses the manual method by going directly to the Village Office "(interview with the Head of the Sungai Bawang Village Administration, 12 February 2019). Whereas what the community as the recipient of the service said was that "administrative management is still the same, we went directly to the village office. This SID program installs wifi, yes, for administrative services, no one is online yet "(interview with Sungai Bawang community, 12 February 2019).

Based on the interview above it can be seen that the performance of the Sungai Bawang Village Government concept is still using manual services that are conducted face to face. After the implementation of the Village Information System program the performance of the Sungai Bawang Village Government did not change significantly. This is because the implementation of Village Information System activities is only at the stage of installing wifi at the village office, while the website and training for administrators and village operators have not yet been done by a third party (PT. ICON $+)$. In fact, according to the Regent of Kuantan Singingi Regency Article 3 point c, administrative services can be carried out through a website-based Village Information System program. Whereas related to admin and village operator training explained in Article 7 point $\mathrm{c}$ that the Village Government (admin and village operator) has the right to receive training as agreed in the employment contract between the Village Government and a third party (ICON +) in July 2017. So it is reviewed in terms of the productivity of the Village Information System program is considered to be less productive because the realization in the field is not in accordance with what should be explained in the Regulation of the District Head of Kuantan Singingi No. 57 of 2017 concerning Village Information Systems.

2. Quality of Service

The issue of service quality tends to become increasingly important in explaining the performance of public service organizations. Many negative views are formed about public organizations arising from public dissatisfaction with the quality of services received from public organizations. in terms of service quality the researcher interviewed the Head of the Sungai Bawang Village Administration stating that "Services here are carried out in accordance with the Standard Operational Procedures (SOP) if there are no obstacles. The service here still uses the concept of manuals up to now "(Interview with Head of Sungai Bawang Village Administration, 12 February 2019) While what is said by the service recipient community is "Administrative management is still manual. The process of making the administration is also still not too long standard if there are no obstacles, but there may also be some administration services that are rather long because there are obstacles. (Interview with Sungai Bawang Village community, 12 February 2019).

Based on the above interview explained that the quality of service received by the community as a service recipient is still in accordance with the Standard Operating Procedures (SOP) that exist if there are no obstacles. The quality of service received by the community before and after the implementation of the Village Information System program has no real impact, because the services provided are still the same, still not manually based on online information technology. Whereas with this Village Information System program, administrative services can be done online according to Kuantan Singingi District Regulations No. 57 of 2017 concerning Village Information System Article 6 point d. But the realization in the field does not tend to be different so it does not affect the quality of service received by the service recipient community.

\section{Responsiveness}

Responsiveness is the ability of organizations to recognize the needs of the community, set agenda and priorities for services, develop public service programs in accordance with the needs and aspirations of the community. In short, responsiveness here refers to the harmony between programs and service activities with the needs and aspirations of the community. Regarding responsiveness, researchers interviewed the Head of the Sungai Bawang Village Administration stating that "In view of the objectives 
of the SID program, we strongly agree, because the current era of information can be widely spread with just one click. Now all of this is electronic based which can be accessed 24 hours. But the realization of what is in the field does not match what should be in the employment contract with ICON +. So yes, like this, only the wifi is installed and now the connection is disconnected. When we report to third parties, they do not provide improvements (Interview with Head of Desa Sungai Bawang Government, 12 February 2019). Meanwhile, when researchers interviewed a third party information was obtained that "for now we just installed wifi, actually we have prepared a website but because there are other things so that the website has not been realized. For training we are also arranging scheduling. Here, one of our obstacles is that many village parties have not yet made payments "(Interview with PT.ICON + Marketing Division, 4 December 2018).

Based on this information it can be seen that the Sungai Bawang Village Government strongly supports the existence of the Village Information System program, which is explored from the objectives of the program itself. But the realization in the field of the program is not in accordance with what should be in the Kuantan Singingi District Regulations No. 57 of 2017 concerning Village Information Systems is to facilitate the public in accessing public information and in order to improve the quality of public services. However, the implementation in the field shows that the Village Information System program is only limited to the installation of wifi, while providing a website as a means of publication and communication between the community and the Village Government has not been realized. Whereas with the website of the village the wider community can access and open opportunities for the village to promote the potential of the village which can be accessed by all people 24 hours. And the condition of the wifi installed in the Village Office is now also disconnected. And when the village government complained about this to a third party (PT. ICON +), the third party did not give a direct response so that until now the condition of the wifi was still disconnected. Meanwhile, what was disclosed by third parties responded that why third parties were less responsive because from the target group (Village Government) many were in arrears. It can be seen that the third party is not committed to the agreed employment contract agreement. Because PT. ICON + does not do maintenance and is not responsive to problems that exist in the target group. So that the purpose of the Village Information System program is not achieved because there is no commitment in maintaining the Village Information System program.

4. Responsibility

Responsibility explains whether the implementation of public organization activities is carried out in accordance with the principles of administration that is correct or in accordance with organizational policies, both explicit and implicit. Therefore, responsibility may one day collide with responsiveness. When the researcher interviewed the Head of the Sungai Bawang Village Administration said that "In carrying out this village information system program we relied on Regent's Regulation No. 57 of 2017 concerning Village Information Systems. But because now the program has no clear road in place so the objectives of the Village Information System program cannot yet be achieved ". (Interview with Sungai Bawang Village Administration Section Head, 12 February 2019). While what was revealed by the Head of the Kuantan Singingi Village Empowerment and Community Empowerment Service said that "The Village Information System Program is based on the Kuantan Singingi District Regulations No. 57 of 2017 concerning Village Information Systems and their derivatives namely Standard Operating Procedure (SOP) for Village Information Systems. But now it is still in the early stages so for the overall objectives of the Village Information System program it has yet to be achieved ". (Interview with the Head of the Community and Village Empowerment Social Service, 12 April 2018).

Based on the interview above it can be seen that the standard used as a reference in implementing the Village Information System program is Kuantan Singingi District Regulations No. 57 of 2017 concerning Village Information Systems and their derivatives namely Standard Operating Procedure (SOP) for Village Information Systems. While the implementation of the Village Information System 
program is still entering its second year so that the overall objectives of the Village Information System program cannot yet be achieved.

\section{Accountability}

Public Accountability refers to how much the policies and activities of public organizations are subject to public officials elected by the people. The assumption is that the political officials because they are elected by the people will automatically represent the interests of the people. the basic concept of public accountability can be used to see how much the policies and activities of public organizations are consistent with the will of many people. The performance of public organizations can not only be seen from the internal measures developed by public or government organizations, such as the achievement of targets. Regarding accountability, the researcher interviewed the Head of the Community and Village Empowerment Social Office who said that "The Village Information System Program is a program of the District Head of Kuantan Singingi which aims to improve the quality of information technology-based public services. While the appointment of a third party is based on the winning bidder ". (Interview with the Head of the Community and Village Empowerment Social Service, 12 April 2018). Meanwhile what was revealed by the Village Finance and Assets Section of the DSPMD said that "The Village Information System Program is guided by Regent's Regulation No. 57 of 2017 concerning Village Information Systems and SID program SOP. From the DSPMD, actually there is no recommend PT.ICON + as a third party. (Interview with DSPMD Village Finance and Asset Section, 14 February 2019). Meanwhile, when the researcher confirmed to the target group in this case the Village Government said that "The SID program is a good goal. However, before we were invited by the Head of the Village in Kuansing, when we were offered the SID program, we rejected it, but there were individuals who came to the Regency Government and approved the SID program because there were still many priority programs that were more needed by the community. However, because of this, we are now implementing the SID program and is only limited to installing wifi ". (Interview with Sungai Bawang Village Administration Section Head, 12 February 2019).

Based on the interview, it can be seen that the existence of the Village Information System program is reviewed from its purpose in accordance with the needs of the current industrial revolution era. However, due to its realization in the field, there were many obstacles encountered so that the Village Information System program had not achieved its overall objectives. And even now there are no significant developments in the SID program. Based on the analysis of researchers there is an element of political interest in the Village Information System program. this can be seen from the agreement between the Village Heads of Kuantan Singingi Regency who initially rejected the Village Information System program, but because there were individuals who agreed, the program was implemented. And create new impacts because the selected third parties are also less competent because they are not committed to maintaining and carrying out their obligations in the Village Information System program as agreed at the time of signing the employment contract between the two parties.

\section{CONCLUSION}

Based on the explanation above it can be concluded that the performance of the Sungai Bawang village government in the Village Information System program is still not optimal. This is because before and after the implementation of the Village Information System program there were no significant changes in the process of providing services to the community and were not in accordance with the indicators contained in Kuntan Singingi District Regulations No. 57 of 2017 concerning Village Information Systems. In addition to being obliged to install wifi at the village office, third parties should also provide a website to the Village Government with the domain "desa.id" and provide training to 
village officials (admin and operator). Viewed from the Productivity indicator, after the implementation of the Village Information System program the performance of the Sungai Bawang Village Government did not change significantly. This is because the implementation of Village Information System activities is only at the stage of installing wifi at the village office, while the website and training for administrators and village operators have not yet been carried out by a third party (PT. ICON + ) so that administrative services cannot be carried out through the website.

Indicators of service quality, the quality of services received by the community before and after the implementation of the Village Information System program have no real impact, because the services provided are still the same, still not based on online information technology. Indicators of responsiveness Here it appears that third parties are not committed to the work contract agreement that has been agreed. Because PT. ICON + does not do maintenance and is not responsive to problems that exist in the target group. So that the purpose of the Village Information System program is not achieved because there is no commitment in maintaining the Village Information System program. Responsibility Indicator, the standard used as a reference in implementing the Village Information System program is Kuantan Singingi District Regulations No. 57 of 2017 concerning Village Information Systems and their derivatives namely Standard Operating Procedure (SOP) for Village Information Systems. While the implementation of the Village Information System program is still entering its second year so that the overall objectives of the Village Information System program cannot yet be achieved. Accountability indicators, there is an element of political interest in the Village Information System program. this can be seen from the agreement between the Village Heads of Kuantan Singingi Regency who initially rejected the Village Information System program, but because there were individuals who agreed, the program was implemented. And create new impacts because the selected third parties are also less competent because they are not committed to maintaining and carrying out their obligations in the Village Information System program as agreed at the time of signing the employment contract between the two parties.

\section{SUGGESTION}

Based on problems related to the Village Information System program in Sungai Bawang Village and to answer the research objectives to be achieved, the researcher suggests:

1. Evaluate the work contract agreement between the two parties namely the third party (PT. ICON + ) and the Village Government so that the Village Information System program can run as it should be contained in the Kuantan Singingi District Regulations No. 57 of 2017 concerning Village Information Systems.

2. It is expected that the implementor and third parties will increase their commitment in implementing the Village Information System program so that the objectives of the Village Information System program can be achieved.

3. It is expected that the relevant parties so that the Village Information System program is not used as political media for certain interests.

\section{BIBLIOGRAPHY}

[1]. Andri Putra Kesmawan, D. M. (2014, Oktober). Implementasi Kebijakan Badan Penyelenggara Jaminan Sosial (BPJS) Kesehatan di Kabupaten Bantul Daerah Istimewa Yogyakarta. Jurnal Ilmu Pemerintahan dan Kebijakan Publik. doi:http://dx.doi.org/10.18196/ 
[2]. Badrudin. (2007). Konsep Dasar Manajemen. Bandung: Alfabeta.

[3]. Linda Muchacha Paramitha, T. D. (n.d.). Kinerja Aparat Pemerintah Desa Dalam Rangka Otonomi Desa (Studi di Desa Gulun, Kecamatan Maospati, Kabupaten Magetan). Jurnal Adminitrasi Publik (JAP), Vol. 1 No. 4, Page 91-100.

[4]. Mohamad Abu Ghazaleh, S. Z. (2018). Ajman Digital Government: the way forward to digest digitalization. Emerald Emerging Markets Case Studies, VOL. 8 NO. 2 2018, 1-20. doi:DOI 10.1108/EEMCS-08-2017-0198

[5]. Nadia Butt, N. F. (2018). Development level of electronic government services: An empirical study of e-government websites in Pakistan. Global Knowledge, Memory and Communication. doi:https://doi.org/10.1108/GKMC-05-2018-0045

[6]. Nilawati, E. (2016, Desember 2). Kinerja Implementasi Program Pengentasan Kemiskinan Melalui Bantuan Keuangan Khusus (BKK) Di Desa Bejiharjo Kecamatan Karangmojo Kabupaten Gunung Kidul. Jurnal Wacana Kinerja, Volume 19 Edisi 2.

[7]. Peraturan Bupati Nomor 57 Tahun 2017 Tentang Sistem Informasi Desa

[8]. Prihati, S. Z. (2018, Januari Hal 2). Kinerja Unit dalam Mendukung Pengembangan Fakultas Ilmu Administrasi Universitas Lancang Kuning. Jurnal Niara, Vol. 10, 106-114.

[9]. Rahmatullah. (2017, 1 1). Implementasi Peraturan Daerah Nomor 10 Tahun 2012Tentang Pengelolaan Tanggung Jawab Sosial Perusahaan di Kota Cilegon. Journal of Indonesian Public Administration and Governance Studies (JIPAGS), Volume 01, page 35-50.

[10]. Sagita, N. I. (2017, Juli 2). Pemanfaatan Teknologi Informasi dalam Penilaian Kinerja Kecamatan dan Kelurahan di Kota Bandung. Journal of Indonesian Public Administration and Governance Studies (JIPAGS), Volume 01 Nomor 02, 182 - 197.

[11]. Standar Operasional Prosedur (SOP) Sistem Informasi Desa

[12]. Tangkilisan, H. N. (2005). Manajemen Publik. Jakarta: PT. Grasindo.

[13]. Tantut Susanto, N. W. (2018). Quality of life of elderly tobacco farmers in the perspective of agricultural nursing: a. Emerald Insight. doi:DOI 10.1108/WWOP-01-2018-0002

[14]. Weerd-Nederhof, P. C. (2001). Qualitative case study research. The case of a PhD research project on organising and managing new product developments system. Management Decision, 513-538. doi:https://doi.org/10.1108/EUM0000000005805

[15]. Wibowo. (2007). Manajemen Kinerja edisi kelima. Jakarta: PT. Rajagrafindo Persada 